\title{
Effect of Marble Powder on the Properties of Self-Compacting Sand Concrete
}

\author{
Bouziani Tayeb* $^{* 1,2}$, Benmounah Abdelbaki ${ }^{1}$, Bederina Madani ${ }^{2}$ and Lamara Mohamed ${ }^{2}$ \\ ${ }^{1}$ Laboratoire des Matériaux Minéraux et Composites LMMC, Université M'hamed Bougara de Boumerdes, 35000 \\ Algeria, ${ }^{2}$ Laboratoire de Recherche de Génie Civil LRGC, Université Amar Telidji de Laghouat, 03000 Algeria
}

\begin{abstract}
Self-compacting sand concrete (SCSC) can be regarded as a flowing sand concrete, containing as principal aggregate natural sand, which can be cast without compaction or vibration. Due to the finesses of aggregates in SCSC, it requires a high amount of fine materials than other types of concretes. This paper studies the effect of marble powder content (MP) on the properties of the sand concrete (SCSC) at fresh and hardened states. The properties of the fresh prepared mixes tested are the mini-slump flow, the V-funnel flow time and viscosity. At the hardened state, the parameter which has been determined is the 28-day compressive strength. The obtained test results show that the increase of MP content in $\mathrm{SCSC}$, from $150 \mathrm{~kg} / \mathrm{m}^{3}$ to $350 \mathrm{~kg} / \mathrm{m}^{3}$, improves the properties at fresh state by decreasing $\mathrm{v}$-funnel flow time (from $5 \mathrm{~s}$ to $1.5 \mathrm{~s}$ ) and increasing the mini-cone slump (from $28 \mathrm{~cm}$ to $34 \mathrm{~cm}$ ). With the use of $250 \mathrm{~kg} / \mathrm{m}^{3}$ of MP we can reach the highest initial viscosity while retaining good fluidity at high rotational speeds, compared to the MP contents of $150 \mathrm{~kg} / \mathrm{m}^{3}$ and $350 \mathrm{~kg} / \mathrm{m}^{3}$. In other hand, the 28-days compressive strength decreases with an increase of MP content.
\end{abstract}

Keywords: Self-compacting sand concrete, marble powder, fresh properties, viscosity, compressive strength.

\section{INTRODUCTION}

Recently, the consumption of aggregates in construction has rapidly increased because of the rapid economic development of countries. The sand concrete is a family of cement concretes which can be used to overcome the economic problems met in the use of coarse aggregates [1]. Moreover, many applications (In France particularly) of self-compacting sand concretes (SCSC) were attempted (concrete of repairs, soil grouting and deep foundations for building) in the project Sablocrete [2]. SCSC can be regarded as a special type of sand concrete, because the constituent materials used in SCSC are essentially the same as those of sand concrete. Normally, sand concrete consist of a mixture of sands, cement, one or more admixtures, additions and water. The main difference between SCSC and the sand concrete is the actual proportioning of these materials. The self-compactability of SCSC may add considerable advantages, especially in filling complex shapes of formworks and coating. In order to achieve such behavior, the fresh concrete must show both high fluidity and sufficient viscosity at the same time [3]. To reach these contradictory properties, all components of SCSC must be carefully selected and proportioned.

Due to the finesses of aggregates, SCSC requires a high water demand and a large amount of cement than other types of concretes. The increase in water content leads to detrimental effects like the bleeding and the segregation as well as weak interfaces between granular materials $[4,5]$.

*Address correspondence to this author at the Laboratoire des Materiaux Minéraux et Composites LMMC, Université M'hamed Bougara de Boumerdes, 35000 Algeria; Tel: +213 248164 08; Fax: +213 248164 08; E-mails: t.bouziani@mail.lagh-univ.dz, t.bouziani@yahoo.fr
Moreover, a high cement content may cause severe creep and drying shrinkage [6], and could categorize SCSC mixes as flowing mortars. Hence, SCSC mixes always contain a superplasticizer and often use a large quantity of fine materials. The superplasticizer is necessary for producing a highly fluid concrete mix, while the fine materials are required to maintain sufficient stability/cohesion of the mix, hence reducing the bleeding, the segregation and the settlement [7].

In SCSC design, the dosage of fine additions has an important influence on the quality of fresh and hardened properties. Bédérina et al. [8] show in a study on the reuse of local sand in sand concretes, the importance of limestone powder content on rheological and mechanical properties. By determining an optimized limestone powder content (in the range of $200 \mathrm{~kg} / \mathrm{m}^{3}$ ), the authors have realized more workable and more resistant dune sand concrete.

Numerous other experimental works revealed that, the concretes containing fine powders, such as limestone powder, have more compact structure by pore-filling effect $[9$, 10]. In a recent study, Jiang and Mei [11] show that a largevolume of fine material is critical to prepare self-compacting concrete made with fine sand. They indicate that the higher the amount of fine materials, the better the workability is. As found by Bhattacharya et al. [12], Self-compacting concretes mixtures with different fine materials and limestone powder fillers have shown consistent slump flow values, although they have shown to produce higher slump flow values compared to other mixtures. In general, the increase of powder materials content to cement leads to the modification of rheological properties of pastes and consequently influences the workability of the concrete mixtures. Ferraris and Gaidis [13] has concluded that the selection criteria of a fine materials addition to improve concrete workability is not in relation 
with their physical or chemical characteristics and can only be determined using the properly designed tests.

In this experimental work, the effect of marble powder (MP) on the properties of fresh and hardened SCSC prepared with natural river sand was studied. For this, three SCSC mixes were prepared in which the binder was composed of cement and MP with different dosages of MP (150, 250 and $350 \mathrm{~kg} / \mathrm{m}^{3}$ ).

\section{EXPERIMENTAL PROGRAM}

\section{Materials}

In this study, ordinary Portland cement (CEM I 42.5) and marble limestone-type powder (MP) derived from marble production sites were used (obtained by sifting to a sieve opening of $80 \mu \mathrm{m}$ ). The main component in MP is $\mathrm{CaCO}_{3}$ (more than 90\%). The specific density and the Blaine area of MP are respectively of 2.7 and 2160. The chemical and physical properties of cement are given in the Table 1 . The particle size distribution obtained thorough sieve analysis method and physical properties of the natural river sand are presented in Table 2. A polycarboxylate-type third generation high range water reducing superplasticizer (SP) conforming to the NF EN 934-2 [14] standard was used. The solid content, $\mathrm{pH}$ and specific gravity are respectively $30 \%$, 6 and 1.07 .

\section{Mixture Proportions}

Based on previous experimental work [8], three SCSC mixtures having constant water to powder ratio (W/P) of 0.44 , constant SP dosage of $1.5 \%$, constant cement content of $350 \mathrm{~kg} / \mathrm{m}^{3}$ and constant sand dosage of $1500 \mathrm{~kg} / \mathrm{m}^{3}$ were prepared. The dosages of MP studied were 150, 250 and 350 $\mathrm{kg} / \mathrm{m}^{3}$. The mix proportions of the SCSC prepared as described above are summarized in Table $\mathbf{3}$.

\section{Testing Procedures}

In order to supply the same homogeneity and uniformity, all the SCSC mixtures are prepared with a constant mixing process. The mixing sequence consists in homogenizing the binder and sand for a minute using standard mixer described by NF EN 196-1 standard [15]. Then, half of the mixing water is added and mixed for a minute. Next, SP with the remaining water is added and the mixing is continued three more minutes. In first, the properties of the fresh SCSC are investigated by using mini-slump, $\mathrm{V}$-funnel and viscosity tests. The mini-slump cone and V-funnel tests (Fig. (1)) were used in conformity with EFNARC [16].
Table 1. Chemical Composition and Physical Properties of Cement

\begin{tabular}{|c|c|}
\hline Analysis & Portland cement \\
\hline \hline $\mathrm{CaO}$ & 65.9 \\
\hline $\mathrm{SiO}_{2}$ & 21.94 \\
\hline $\mathrm{Al}_{2} \mathrm{O}_{3}$ & 4.82 \\
\hline $\mathrm{Fe}_{2} \mathrm{O}_{3}$ & 3.94 \\
\hline $\mathrm{MgO}$ & 1.65 \\
\hline $\mathrm{K}_{2} \mathrm{O}$ & 0.6 \\
\hline $\mathrm{SO}_{3}$ & 0.48 \\
\hline $\mathrm{Na}_{2} \mathrm{O}$ & 0.1 \\
\hline $\mathrm{Cl}$ & $/$ \\
\hline Specific density & 3.1 \\
\hline Blaine Surface $\left(\mathrm{cm}^{2} / \mathrm{g}\right)$ & 2900 \\
\hline
\end{tabular}

Table 2. Sieve Analysis and Physical Properties of Natural River Sand

\begin{tabular}{|c|c|}
\hline Sieve size (mm) & Cumulative passing (\%) \\
\hline \hline 5 & 99.5 \\
\hline 4 & 97.09 \\
\hline 2.5 & 83.56 \\
\hline 1.25 & 63.27 \\
\hline 0.63 & 34.85 \\
\hline 0.315 & 13.65 \\
\hline 0.16 & 2.44 \\
\hline 0.08 & 0.84 \\
\hline Specific gravity & 2.56 \\
\hline Fineness modulus & 3.03 \\
\hline Sand equivalent & 87.7 \\
\hline Absorption (\%) & 1.79 \\
\hline
\end{tabular}

The viscosity was measured using a programmable DVII+ rotational viscometer equipped with the RV 4 mobile geometry (Fig. (2)). The viscosity measurements were con-

Table 3. Mix Proportions of Prepared SCSC

\begin{tabular}{|c|c|c|c|c|c|c|c|}
\hline \multirow{2}{*}{ Component } & $\mathbf{S P}$ & \multirow{2}{*}{$\mathbf{W} / \mathbf{P}$} & Cement & MP & Binder & $\mathbf{S P}$ & Water \\
\hline & $(\%)$ & & \multicolumn{5}{|c|}{$\left(\mathrm{kg} / \mathrm{m}^{3}\right)$} \\
\hline Mix 1 & 1.5 & 0.44 & 350 & 150 & 500 & 7.5 & 220 \\
\hline Mix 2 & 1.5 & 0.44 & 350 & 250 & 600 & 9 & 264 \\
\hline Mix 3 & 1.5 & 0.44 & 350 & 350 & 700 & 10.5 & 308 \\
\hline
\end{tabular}




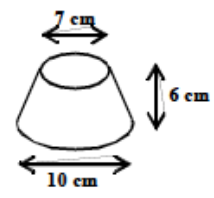

(a)

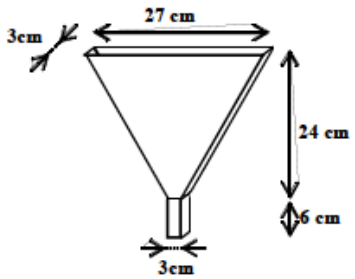

(b)
Fig. (1). Dimensions in (cm) of mini-slump cone and V-funnel tests used.

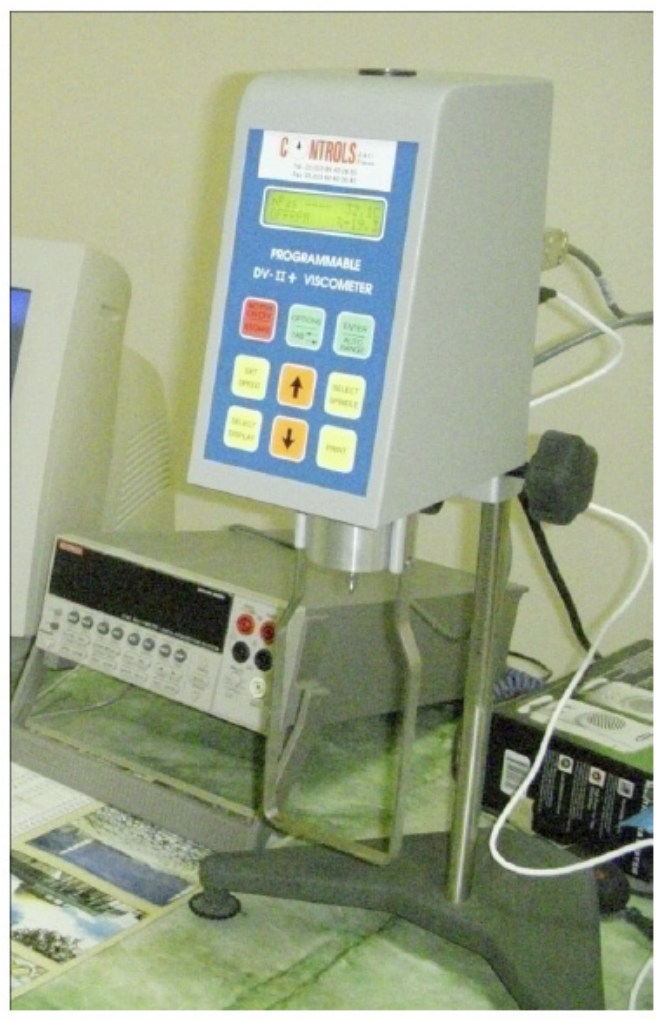

Fig. (2). Programmable DV-II+ viscometer.

ducted at different rotational speeds. The SCSC was prepared and placed on the pot of the viscometer. Pre-mixing was performed by increasing the rotational speed from 0 to $60 \mathrm{rpm}$ in $120 \mathrm{~s}$. When the highest rotational speed was reached, the viscometer was stopped. After this initial preparation, a full cycle of increasing rotational speed occurring by 8 steps from $0.3 \mathrm{rpm}$ to $60 \mathrm{rpm}$ and back to reset with another 8 steps was performed. The average of viscosity values determined at upwards and downwards of each rotational speed steps were recorded. This procedure was performed at $0 \mathrm{~min}$ and repeated at $20 \mathrm{~min}$ [17].

The tests of compressive strength of hardened SCSC were also measured. Specimens were casted in moulds made of stainless steels having as dimensions $40 \times 40 \times 160 \mathrm{~mm}$. The specimens were demoulded one day after casting and were placed in a water bath with a constant temperature. The tests were carried out at 28 days.

\section{RESULTS AND DISCUSSIONS}

The effect of MP content on evolution in the mini-slump flow and the V-funnel time flow are respectively illustrated in Figs. (3) and (4). It's clear that the mini-slump flow values increase with an increase in MP content (Fig. (3)). The Vfunnel flow time decreased with an increase in MP content, as seen in Fig. (4). In other words, the flowability of the SCSC mixes increases with an increase in MP content.

The results of viscosity measurement show that the behaviour of all the studied mixtures is similar and can be best fitted with the power law model $\left(\mu=a \cdot \gamma^{b}\right)$, in which $\mu$ is the viscosity, $\gamma$ is the rotational speed of mobile, $a$ and $b$ are the model coefficients. The coefficient $a$ is also called the consistency index, which characterizes the initial viscosity and the coefficient $b$ is called the flow index. In this work, the coefficients $a$ and $b$ are used to characterize the viscosity of the SCSC. The viscosity variation of all SCSC mixtures as a function of rotational speed is represented in full-log scale curves (Figs. (5) and (6)). It can be observed that at a low rotational speed, a viscous behaviour is marked, whereas at high rotational speed a flowable behaviour is dominant. It can also be observed a viscous behaviour of mixtures with time (at $\mathrm{T}=20 \mathrm{~min}$ ). It should be noted that these results are in agreement with recent studies [17-19].

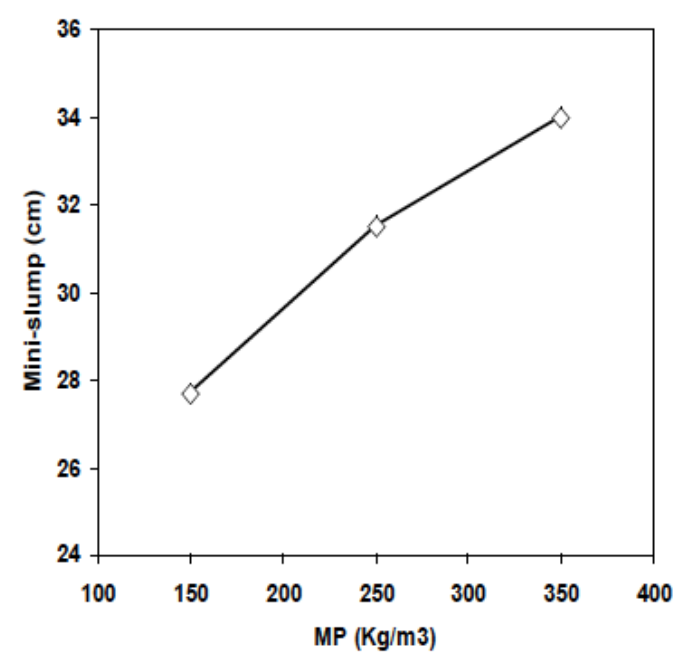

Fig. (3). Effect of MP on the mini-slump flow of SCSC.

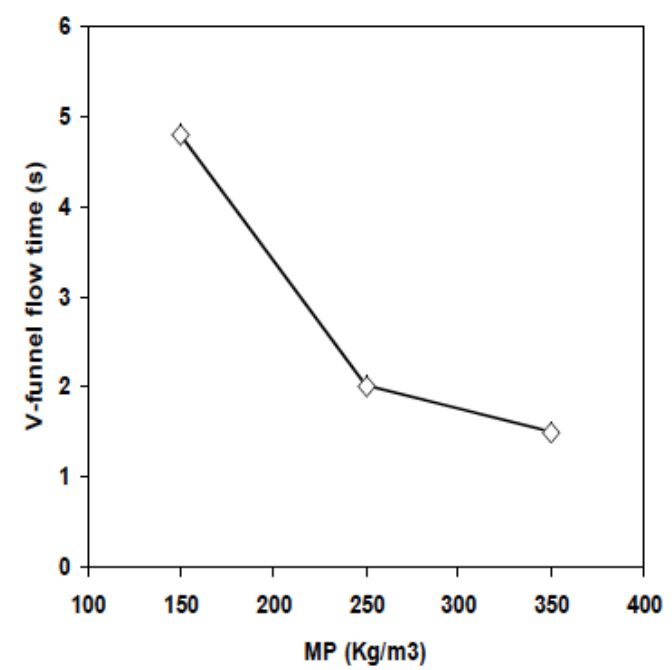

Fig. (4). Effect of MP on the V-funnel flow time of SCSC. 


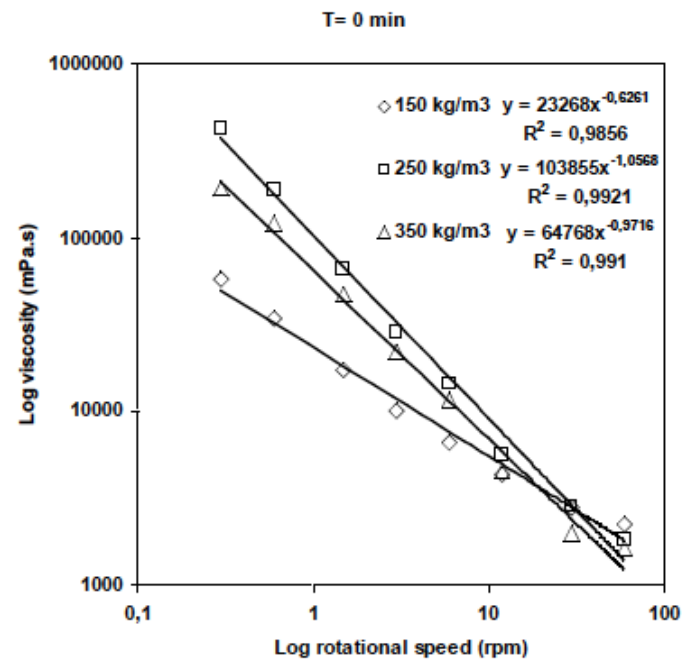

Fig. (5). Effect of MP content on viscosity of SCSC at $\mathrm{T}=0 \mathrm{~min}$.

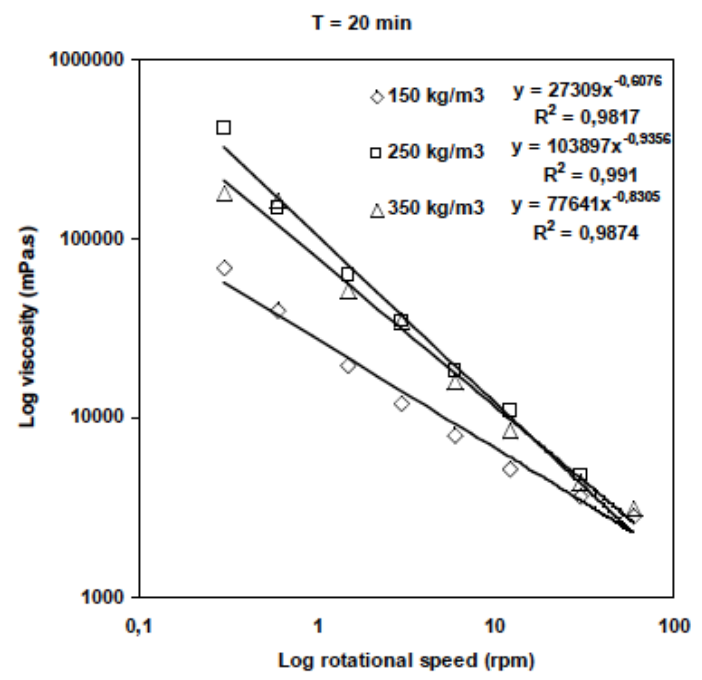

Fig. (6). Effect of MP content on viscosity of SCSC at $\mathrm{T}=20 \mathrm{~min}$.

Using the viscosity model coefficients, the initial viscosity can be characterized by the consistency index (a), and the needed energy necessary to attain a flowable consistency can be characterized by the flow index (b) (which represents the slope of line). In other words, the higher $a$ is, the larger the initial viscosity will be and the higher $b$ is, the lower the needed energy necessary to attain a flowable consistency will be.

As represented in Figs. (5) and (6), the highest values of $a$, is obtained in the case of $250 \mathrm{~kg} / \mathrm{m} 3$ of MP. It can also be observed that for high rotational speeds (up to $30 \mathrm{rpm}$ ) the mixtures containing 350 and $250 \mathrm{~kg} / \mathrm{m}^{3}$ of MP show more flowable consistency than the mixture made with $150 \mathrm{~kg} / \mathrm{m} 3$. We can also see that the lowest values of $b$ are obtained in the case of $250 \mathrm{~kg} / \mathrm{m}^{3}$ of MP. This behaviour allows to mixture to have a good fluidity during the flow and to develop certain viscosity when flow ceases. The effect of MP content on the SCSC mixes is similar after 20 min with a more viscous behaviour. The compressive strength results of hardened SCSC are given in Fig. (7). From these results, it can be seen that, at 28-day age, the compressive strength decreases with an increase in MP content from $150 \mathrm{~kg} / \mathrm{m}^{3}$ to 350

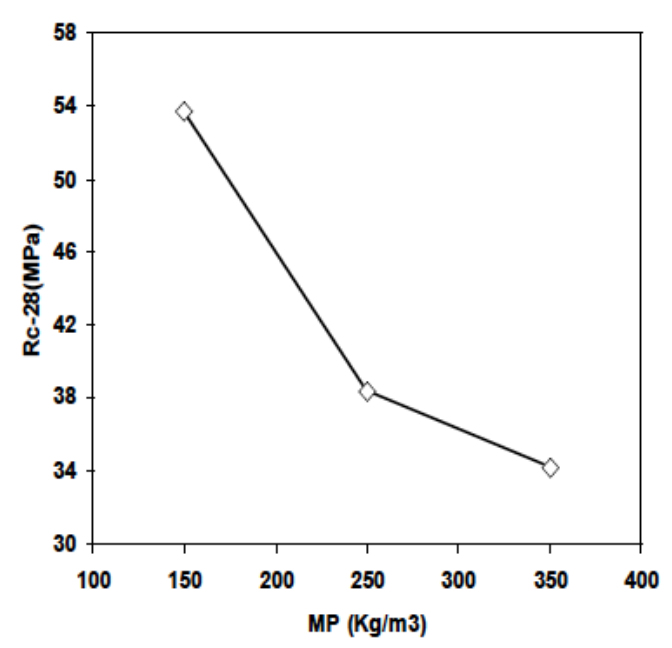

Fig. (7). Effect of MP on 28-days compressive strength of SCSC.

$\mathrm{kg} / \mathrm{m}^{3}$. The detrimental effect of adding MP on the strength of the SCSC was actually due to the increase in water/cement ratio as MP content increased.

\section{CONCLUSIONS}

The following conclusions can be drawn from the present study:

1- The increase of MP dosage in SCSC increases both of the mini-slump flow and the $\mathrm{V}$-funnel flow time.

2- By using the consistency index (a) and the flow index (b) of the viscosity model of the best fitted curves, the initial viscosity and the needed energy necessary to attain a flowable consistency can be characterized. In other words, the higher $a$ is, the larger the initial viscosity is, and the higher $b$ is, the lower the needed energy necessary to attain a flowable consistency is.

3- With $250 \mathrm{~kg} / \mathrm{m}^{3}$ of MP, SCSC have the highest values of $a$ and the lowest values of $b$. This dosage is suitable for SCSC, because it allows to the mixture to have good fluidity during the flow (up to $30 \mathrm{rpm}$ ) while presenting a sufficient viscosity at the end of the flow which allows to avoid the segregation.

4- Despite the positive effect of MP on the fluidity of SCSC, their addition must be controlled according to the mechanical strength question. The addition of MP to SCSC requires an increase in water/cement ratio, which leads to a decrease in compressive strength at 28 days.

\section{REFERENCES}

[1] T. S. Nguyen, and D. H. Phan, "An Experimental Research on Sand Concrete in Mekong Delta", in proceeding of the 3rd International Conference- ACF/VCA on Sustainable Concrete Technology and Structures in Local Climate and Environment conditions, Vietnam, 2008, pp.455-461.

[2] Sablocrete, Projet National de Recherche et Développement, Bétons de sable: caractéristiques et pratiques d'utilisation, Edition de l'Ecole Nationale des Ponts et Chaussées (ENPC), France, pp. 15$199,1994$.

[3] V. Corinaldesi, and G. Moriconi, "Durable fibre reinforced selfcompacting concrete", Cement and Concrete Research, vol. 34, No. 2, pp. 249-254, 2004.

[4] S. H. Kosmatka, B. Kerkhoff, and W. C. Panarese, "Design and Control of Concrete Mixtures", $14^{\text {th }}$ ed. Portland Cement Association (PCA), United States, 2003. 
[5] P. K. Mehta, and J. M. Monteiro, Concrete: Structure, properties and materials, Prentice-Hall: Englewood Cliff, NJ, 1993.

[6] P. K. Chang, C. L. Hwang, and Y. N. Peng, "Application of high performance concrete to high rise building in Taiwan", Advances in Structural Engineering, vol. 4, No. 2, pp. 65-73, 2001.

[7] W. Zhu, and J. C. Gibbs, "Use of different limestone and chalk powders in self-compacting concrete", Cement and Concrete Research, vol. 35, pp. 1457-1462, 2005.

[8] M. Bédérina, M. M. Khenfer, R. M. Dheilly, and M. Quéneudec, "Reuse of local sand: effect of limestone filler proportion on the rheological and mechanical properties of different sand concretes", Cement and Concrete Research, vol. 35, pp. 1172-1179, 2005.

[9] B. Felekoğlu, and B. Baradan, "Utilisation of Limestone Powder in Self-Levelling Binders", in the Proceedings of the International Symposium on Advances in Waste Management and Recycling, Thomas Telford Ltd., pp. 475-484, London, UK, 2003.

[10] K. E. Alyamaç, and R. Ince, "A preliminary mix design for SCC with marble powders", Construction and Building Materials, vol. 23, pp. 1201-1210, 2009.

[11] Z. Jiang, and S. Mei, "Properties of self-compacting concrete with machine-made sand and high-volume mineral admixtures", The Open Construction and Building Technology Journal, vol. 2, pp. 96-102, 2008.

[12] A. Bhattacharya, I. Ray, and J.F. Davalos, "Effects of aggregate grading and admixture/filler on self-consolidating concrete", The
Open Construction and Building Technology Journal, vol. 2, pp. $89-95,2008$.

[13] C. F. Ferraris, and J. M. Gaidis, "Connection between the rheology of concrete and rheology of cement paste", ACI Materials Journal, vol. 89, No. 4, pp. 388-393, 1992.

[14] NF EN 934-2, Normes Afnor, Béton et constituants des bétons, Tome 1: spécification du béton et de ses constituants, AFNOR Edition, France, 2002, p. 432

[15] NF EN 196-1, Normes Afnor, Ciments et Chaux, AFNOR Edition, France, 2003, p. 548.

[16] EFNARC recommandantions, The European guidelines for selfcompacting concrete, Specification, Production and use, web site: http://www.efnarc.org/pdf/SandGforSCC.PDF, EFNARC Edition, United Kingdom, p. 63, February 2002.

[17] B. Felekoğlu, K. Tosun, B. Baradan, A. Altun, and B. Uyulgan, "The effect of fly ash and limestone fillers on the viscosity and compressive strength of self-compacting repair mortars", Cement and Concrete Research, vol. 36, pp. 1719-1726, 2006.

[18] Z. Sun, T. Voigt, and S. P. Shah, "Rheometric and ultrasonic investigations of viscoelastic properties of fresh Portland cement pastes", Cement and Concrete Research, vol. 36, No. 2, pp. 278-287, 2006.

[19] E. Güneyisi, and M. Gesoğlu, "Properties of self-compacting mortars with binary and ternary cementitious blends of fly ash and metakaolin", Materials and Structures, vol. 41, No. 9, pp. 1519$1531,2008$.

(C) Tayeb et al.; Licensee Bentham Open.

This is an open access article licensed under the terms of the Creative Commons Attribution Non-Commercial License (http://creativecommons.org/licenses/by-nc/3.0/) which permits unrestricted, non-commercial use, distribution and reproduction in any medium, provided the work is properly cited. 